\title{
A new strain of Cryptocaryon irritans from the cultured olive flounder Paralichthys olivaceus
}

\author{
Bo-Young Jee ${ }^{1, *}$, Ki Hong Kim², Soo-Il Park ${ }^{2}$, Yi-Cheung Kim ${ }^{1}$ \\ ${ }^{1}$ Pathology Division, National Fisheries Research and Development Institute, 408-1, Kijang, Pusan 619-900, Korea \\ ${ }^{2}$ Department of Aquatic Life Medicine, Pukyong National University, 599-1, Daeyun, Pusan 608-737, Korea
}

\begin{abstract}
An obligate parasite, Cryptocaryon irritans, which is responsible for the white spot disease of marine fish is known to develop in the temperature regime over $19^{\circ} \mathrm{C}$. Recently, however, we found white spot disease of olive flounder Paralichthys olivaceus during winter at water temperatures ranging between 12 and $16^{\circ} \mathrm{C}$ in Korea. In the present study we isolated a C. irritans-like ciliate from the affected fish and investigated its reproductive characters to compare the newly found ciliate with typical $C$. irritans. The newly found ciliate had an additional process in the reproductive stage, characterized by a budding before palintomic division, and it showed a higher ability to carry out tomitogenesis at a low temperature $\left(16^{\circ} \mathrm{C}\right)$ than at a high temperature $\left(24^{\circ} \mathrm{C}\right)$. Nevertheless, the present ciliates still had much in common with typical $C$. irritans with respect to clinical, histopathological, and morphological characters, suggesting that it is a new strain of $C$. irritans, adapted to lower water temperature.
\end{abstract}

KEY WORDS: Cryptocaryon irritans-like ciliate $\cdot$ White spot disease $\cdot$ Olive flounder

\section{INTRODUCTION}

White spot disease of marine fish caused by Cryptocaryon irritans Brown 1951 has been a major problem in the development of mariculture (Nigrelli \& Ruggieri 1966, Cheung et al. 1980, 1981), accounting for high mortalities in cultured food fishes (Huff \& Burns 1981, Colorni 1985, Kaige \& Miyazaki 1985, Dimant et al. 1991). C. irritans is an obligate parasite of warm-water marine fish from areas where minimum sea temperatures exceed $19^{\circ} \mathrm{C}$ (Wilkie \& Gordin 1969). The lifecycle of the parasite is direct: growth and development takes place within the fish epidermis, and a free-living phase follows in which the parasite forms a cyst, then undergoes several divisions and produces theronts (Brown 1963, Colorni 1985, Lom \& Dykova 1992, Burgess \& Matthews 1994). In Korea, marine fish such as olive flounder Paralichthys olivaceus, red seabream Pagrus major and puffer Takifugu obscrus cultured at several fish farms were frequently affected by the

*E-mail: protjee@haema.nfrda.re.kr parasites during high water-temperature periods. Recently, however, we found white spot disease of olive flounder during the winter season at water temperatures ranging between 12 and $16^{\circ} \mathrm{C}$. In the present study, we investigated the reproductive characteristics of the ciliates found and compared them with typical C. irritans.

\section{MATERIALS AND METHODS}

Fish. From December 1997 to February 1998, olive flounder Paralichthys olivaceus weighing 150 to $300 \mathrm{~g}$ and showing white spots on the skin were obtained from an embankment farm on the East Coast of the Korean peninsula.

Histopathology. Tissue of infected fish was fixed in $10 \%$ neutral formalin. Following serial dehydration with ethanol, tissue was embedded in paraffin wax. Sections 4 to $5 \mu \mathrm{m}$ in thickness were stained with hematoxylineosin or Giemsa for light microscopic observation.

Morphology. The morphological characteristics of trophonts, tomonts and theronts were observed with a 
light or phase-contrast microscope, and the sizes of each stage were measured with a micrometer.

Reproduction. The detached mature trophonts were transferred to a 96-well plate filled with filtered seawater, and incubated at $16^{\circ} \mathrm{C}$. The morphological changes and reproductive patterns were observed daily with a phase-contrast microscope. To determine whether water temperature influences tomite development and excystment, 2 groups of ciliates (28 and 32 individuals) were incubated at 2 different temperatures (16 and $24^{\circ} \mathrm{C}$, respectively). The experiment was carried out 4 times with a total number of 240 populations. The time to beginning of excystment and success rate of excystment was recorded daily. For experimental infections under laboratory conditions, 10 healthy, juvenile flounders in a $30 \mathrm{l}$ seawater aquarium $\left(16^{\circ} \mathrm{C}\right.$, $32 \pm 2 \%$ ) were cohabited with 2 infected fish.

\section{RESULTS}

\section{Clinical signs}

The infected fish showed multiple pin-point sized white spots on the body surface, fins and gills (Fig. 1). An excessive production of mucus on the body surface and the gills was seen in affected fish. No clinical signs of disease were seen in the internal organs of the fish.

\section{Histopathology}

Many ciliates were found above the basal membrane in the epithelium of gill filaments and skin, and caused hyperplasia of epithelial and mucus cells in the parasitic areas. In the gills, a large ciliate was observed in the blood vessel of primary gill filaments. Sometimes, a small ciliate was found in the interlamellar space in the early stage of infection and evoked slight epithelial proliferation. In the skin, ciliates of variable sizes were seen in the subepithelia, and caused marked hyperplasia of mucus cells. Empty spaces were present along with vacuolated and necrotic cells (Fig. 2).

\section{Morphology}

The general morphology of the present ciliates was similar to that of typical Cryptocaryon irritans, but they were larger than typical C. irritans (Table 1).

\section{Reproduction pattern}

The detached, mature trophonts formed a cyst wall, then the encysted cell divided into 3 to 6 equal size cells by budding within a few hours. During the division process, each budding cell went through the cyst wall and formed a new cyst wall (Fig. 3). Each divided

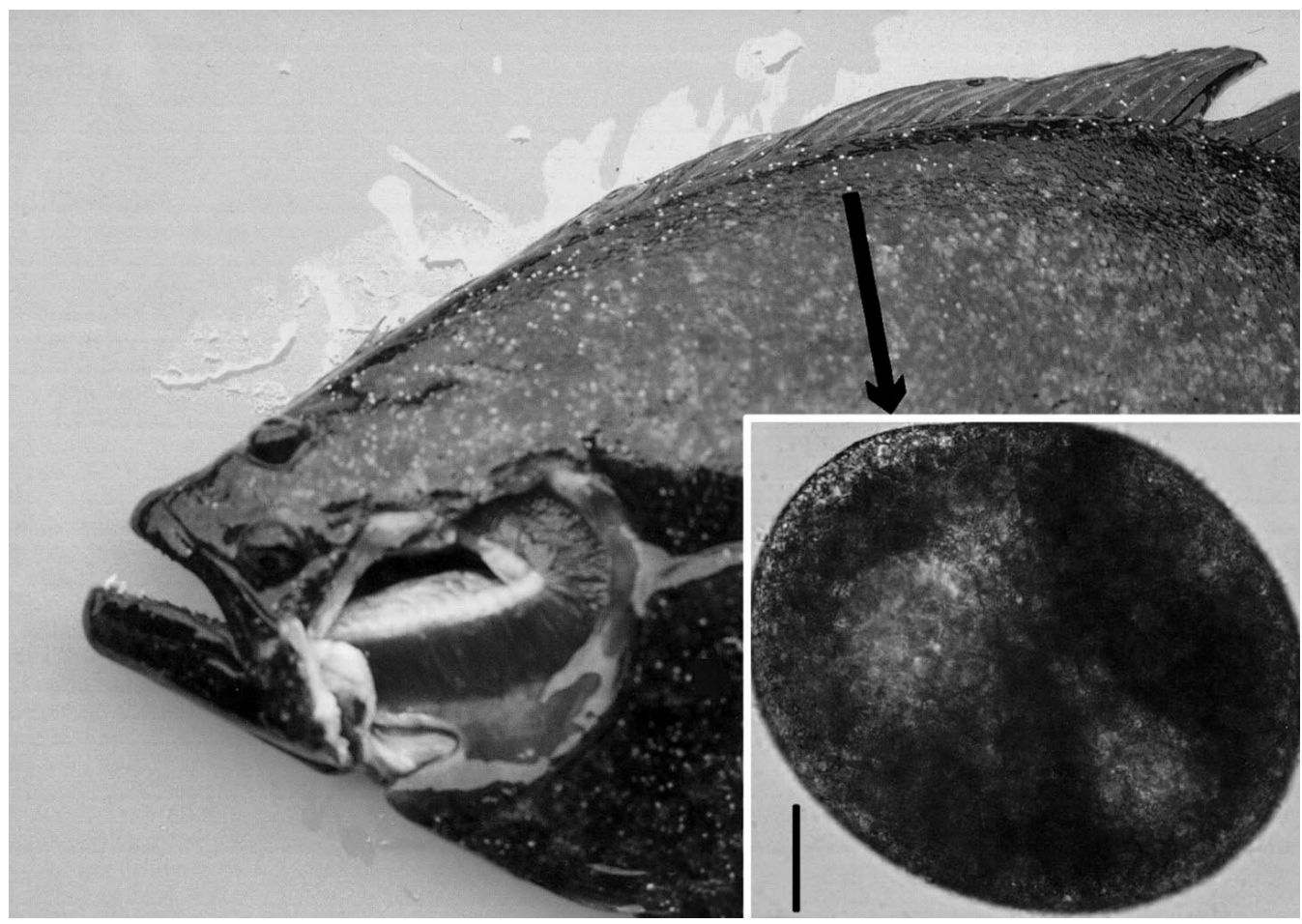

Fig. 1. White spots on the gill and skin of the olive flounder Paralichthys olivaceus. Note spherical shape of trophont under light microscopy (arrow). Scale bar $=100 \mu \mathrm{m}$ 
Fig. 2. Necrotic area of the skin from olive flounder showing parasite (P). H\&E

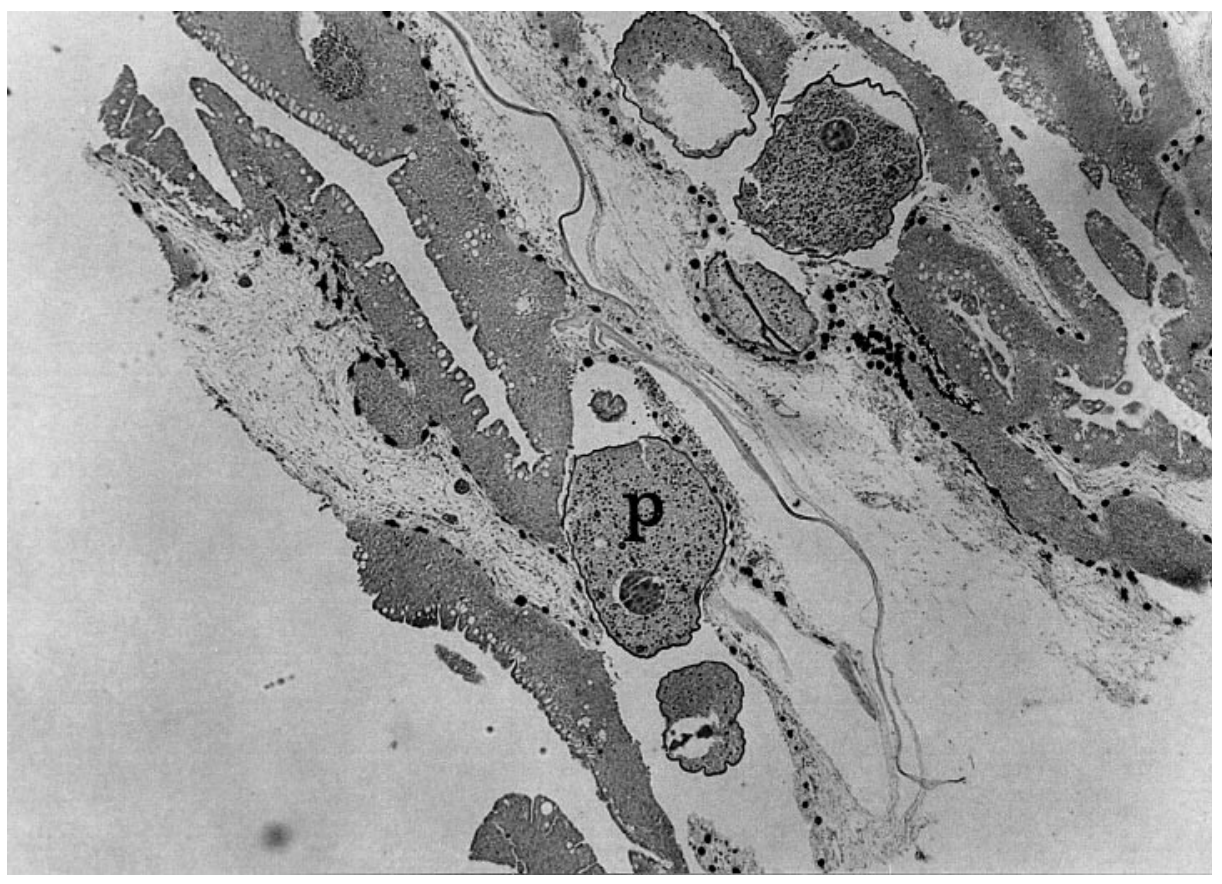

tomont underwent a series of divisions and produced tomites. The number of tomites produced per daughter tomont was no more than 100 . The time to complete tomitogenesis was 13 to $15 \mathrm{~d}$ at $16^{\circ} \mathrm{C}$ and 7 to $13 \mathrm{~d}$ at $24^{\circ} \mathrm{C}$. The success rate of tomite production was $76.6 \%$ at $16^{\circ} \mathrm{C}$ and $31.6 \%$ at $24^{\circ} \mathrm{C}$ (Table 2). In the infection experiment, 3 fish among 10 juveniles showed white spots on the body surface on Day 4 after exposure. The trophonts released from the infected juveniles showed reproductive patterns identical to those mentioned above.

\section{DISCUSSION}

Diggles \& Lester (1996b) reported that the heaviest infection of Cryptocaryon irritans on Acanthopagrus austrails occurred at $17^{\circ} \mathrm{C}$ and infections were still recorded at $15^{\circ} \mathrm{C}$, a temperature at which C. irritans infections were found not to occur in previous studies (Wilkie \& Gordin 1969). This suggested the possible existence of different strains of $C$. irritanse which can be differentiated by their temperature tolerance. The present study demonstrates that white spot disease also occurs at low water temperature in cultured olive flounder. The considerably higher success rate of tomites production at 16 than at $24^{\circ} \mathrm{C}$ clearly indicates that these ciliates are well adapted to low water temperature.

The clinical and histopathological signs of the present infected fish showed more excessive mucus production and hyperplasia of epithelial cells in the gill lamellae than in the previous reports (Nigrelli \& Ruggieri 1966, Kaige \& Miyazaki 1985).

Diggles \& Lester (1996a) reported that Cryptocaryon irritans exhibited morphometric variability on different

Table 1. Comparison of Cryptocaryon irritans from the literature and the ciliates recovered from olive flounder Paralichthys olivaceus

\begin{tabular}{|lccccc|}
\hline & $\begin{array}{c}\text { Brown } \\
(1951)\end{array}$ & $\begin{array}{c}\text { Nigrelli \& } \\
\text { Ruggieri (1966) }\end{array}$ & Colorni (1985) & $\begin{array}{c}\text { Burgess \& } \\
\text { Matthews (1994) }\end{array}$ & $\begin{array}{c}\text { Present } \\
\text { study }\end{array}$ \\
\hline Hosts & Various & Various & Sparus aurata & Chelon labrosus & Paralichthys olivaceus \\
Temperature $\left({ }^{\circ} \mathrm{C}\right)$ & $20-25$ & $22-25$ & $23-25$ & $24-26$ & $12-16$ \\
Mean trophont diameter $(\mu \mathrm{m})$ & $180-450$ & $350-450$ & - & $203-452$ & $350-700$ \\
Mean tomont diameter $(\mu \mathrm{m})$ & $200-450$ & $170-441$ & $160-370$ & $160-406$ & $300-700$ \\
Mean theront diameter $(\mu \mathrm{m})$ & $40-75$ & 57 & $50-70$ & $40-69$ & $60-100$ \\
Reproduction pattern & Palintomy & Palintomy & Palintomy & Palintomy & Budding and palintomy \\
No. of theront/tomont & - & Up to 200 & No more & $119-292$ & No more \\
& & or more & than 200 & & than 100 \\
& & & & &
\end{tabular}



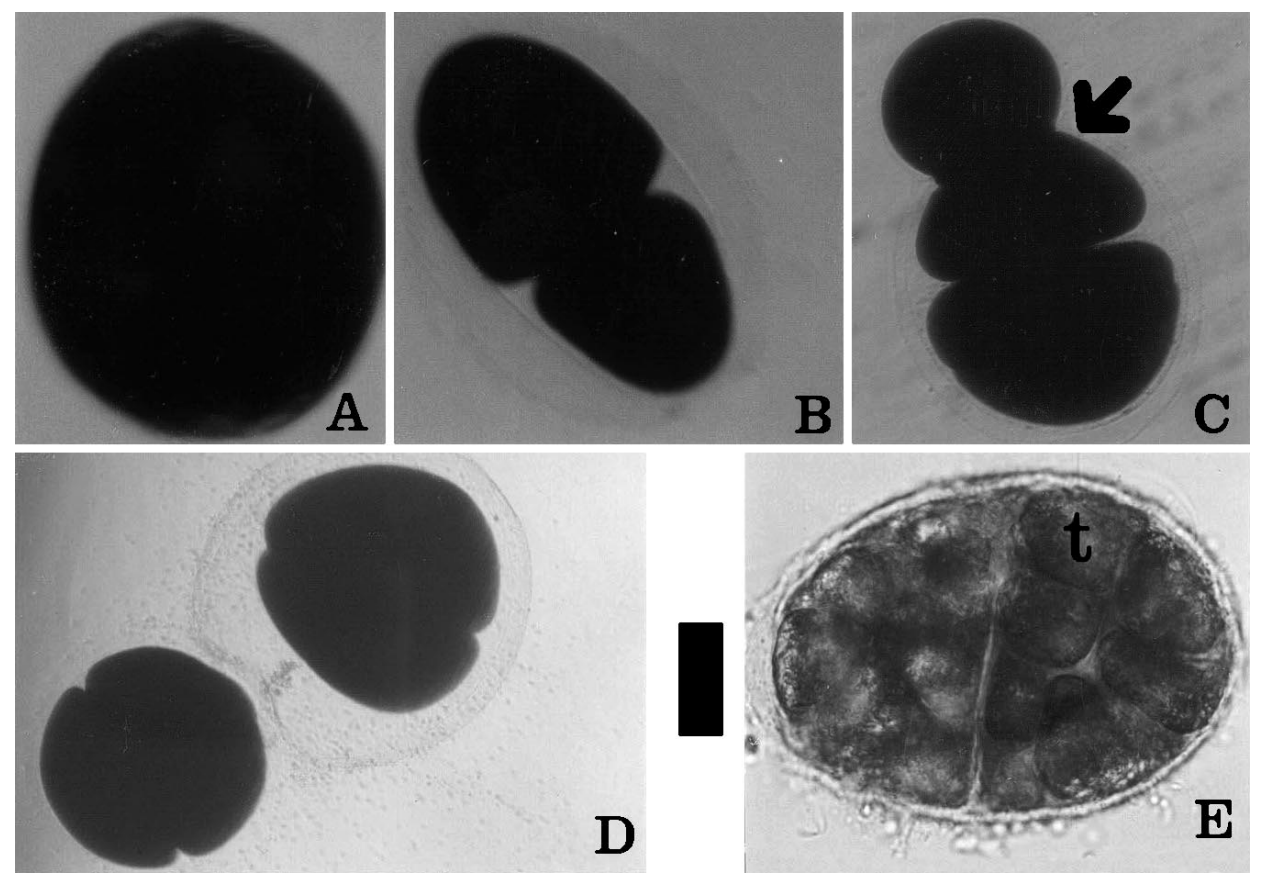

Fig. 3. Reproduction of the parasite recovered from olive flounder. Live specimen. Scale bar $=100 \mu \mathrm{m}$. (A) Free-swimming ciliate. (B) Ciliate reproducing within cyst. (C) Daughter cell budding out from a cyst (arrow). (D) Daughter cell forming a new cyst wall. (E) Daughter cell showing palintomy division within the cyst
Table 2. Effects of temperatures on tomitogenesis at constant salinity $(35 \%)$. Each value represents the mean of 4 replicate experiments

\begin{tabular}{|lccccc|}
\hline $\begin{array}{l}\text { Temper- } \\
\text { ature }\left({ }^{\circ} \mathrm{C}\right)\end{array}$ & $\begin{array}{c}\text { No. } \\
\text { collected }\end{array}$ & $\begin{array}{c}\text { No. } \\
\text { encysted }\end{array}$ & $\begin{array}{c}\text { No. } \\
\text { excysted }\end{array}$ & $\begin{array}{c}\text { Encysted } \\
\text { rate }(\%)\end{array}$ & $\begin{array}{c}\text { Encysted } \\
\text { time (day) }\end{array}$ \\
\hline 16 & 30 & 24 & 23 & 76.6 & $13-15$ \\
24 & 32 & 13 & 10 & 31.6 & $7-13$ \\
\hline
\end{tabular}

encysted ciliate (tomont) undergoes a series of divisions producing numerous tomites. Compared to the reproduction pattern of typical C. irritans described in other reports, the present ciliates showed a different sequence of divisions, i.e., production of several daughter tomonts by budding before palintomic division. This peculiar reproduction pattern of $C$. irritans has not been reported previously. Therefore, we tentatively define the

hosts and under different temperature conditions. Diggles \& Lester (1996b) also found that the size of $C$. irritans varied inversely with water temperature. A similar relationship between water temperature and parasite size is well known for Ichthyophthirius multifiliis (MacLennan 1942) and Amylloodinium ocellatum (Paperna 1984). Although the size of the present ciliates in all life stages was larger than that reported for $C$. irritans (Brown 1963, Nigrelli \& Ruggieri 1966, Cheung et al. 1981, Colorni 1987, Colorni \& Diamant 1993), there were no differences in morphological features. It seems that the fact that present ciliates were larger than the typical $C$. irritans resulted from lower ambient temperatures, which was also pointed out by Diggles \& Lester (1996b).

There are numerous reports on the reproduction pattern of Cryptocaryon irritans (Brown 1963, Nigrelli \& Ruggieri 1966, Cheung et al. 1980, Colorni 1987, Colorni \& Diamant 1993). According to these reports, reproduction starts when a mature trophont drops off the host and forms a cyst wall without a host. The present ciliate population as a new strain of $C$. irritans which has adapted to a new environment, mainly to lower water temperature.

\section{LITERATURE CITED}

Brown (1951) A new parasitic protozoan, the causal organism of a white spot disease in marine fish Cryptocaryon irritans gen and sp. m. Agen Sci Meet Zool Soc Lond 1950 11:1-2

Brown EM (1963) Studies on Cryptocaryon irritans Brown. Progress in Protozoology. Proc 1st Int Cong Protozoology. Academic Press, New York, p 284-287

Burgess PJ, Matthews MA (1994) A standardized method for the in vivo maintenance of Cryptocaryon irritans (Ciliophora) using the grey mullet Chelon labrosus as an experimental host. J Parasitol 80:288-292

Cheung PJ, Nigrelli RF, Ruggieri GD (1980) Studies on cryptocaryoniasis in marine fish: effect of temperature and salinity on reproductive cycle of Cryptocaryon irritans Brown, 1951. J Fish Dis 2:93-97

Cheung PJ, Nigrelli RF, Ruggieri GD (1981) Scanning electron microscopy on Cryptocaryon irritans Brown, 1951, a 
parasitic ciliate in marine fish. J Aquacult 2:70-72

Colorni A (1985) Aspects of the biology of Cryptocaryon irritans and hyposalinity as a control measure in cultured gilthead sea bream Sparus aurata. Dis Aquat Org 1:19-27

Colorni A (1987) Biology of Cryptocaryon irritans and stratergies for its control. Aquaculture 67:236-237

Colorni A, Diamant A (1993) Ultrastructural features of Cryptocaryon irritans, a ciliate parasite of marine fish. Eur J Protistol 29:425-434

Diamant A, Issar G, Colorni A, Paperna I (1991) A pathogenic Cryptocaryon-like ciliate from the Mediterranean Sea. Bull Eur Assoc Fish Pathol 11:122-124

Diggles BK, Lester RTJ (1996a) Influence of temperature and host species on the devlopment of Cryptocaryon irritans. J Parasitol 82:45-52

Diggles BK, Lester RTJ (1996b) Infections of Cryptocaryon irritans on wild fish from southeast Queensland, Australia. Dis Aquat Org 25:159-167

Huff JA, Burns CD (1981) Hypersaline and chemical control

Editorial responsibility: Wolfgang Körting,

Hannover, Germany of Cryptocaryon irritans in red snapper, Lutjanus campechanus, monoculture. Aquaculture 22:181-184

Kaige N, Miyazaki T (1985) A histopathological study of white spot disease in Japanese flounder. Fish Pathol 20:61-64

Lom J, Dykova I (1992) Protozoan parasites of fish. Dev Aquac Fish Sci 26:258-259

MacLennan RF (1942) Growth in the ciliate Ichthyophthirius, Vol II. J Exp Zool 91:1-3

Nigrelli RF, Ruggieri GD (1966) Enzootics in the New York Aquarium caused by Cryptocaryon irritans Brown, 1951 (=Ichthyophthirius marinus Sikama, 1961), a histophagous ciliate in the skin, eyes and gills of marine fish. Zoologica 51:97-102

Paperna I (1984) Reproduction cycle and tolerance to temperature and salinity of Amyloodinium ocellatum (Brown 1931) (Dinoflagellidae). Ann Parasitol Hum Com 59:7-30

Wilkie DW, Gordin H (1969) Outbreak of cryptocaryoniasis in marine aquaria at Scripps Institute of Oceanography. Calif Fish Game 55:227-236

Submitted: January 3, 2000; Accepted: July 31, 2000

Proofs received from author(s): December 12, 2000 